Jurnal e-GiGi (eG), Volume 2, Nomor 2, Juli-Desember 2014

\title{
GAMBARAN PENGGUNAAN MATERIAL RESTORASI SEMEN IONOMER KACA DI POLI GIGI RUMAH SAKIT BHAYANGKARA MANADO
}

\author{
${ }^{1}$ Myrtle Irene Sarjono \\ ${ }^{2}$ Dinar A. Wicaksono \\ ${ }^{3}$ Damayanti H.C. Pangemanan
}

\author{
${ }^{1}$ Kandidat Skripsi Program Studi Pendidikan Dokter Gigi \\ ${ }^{2}$ Program Studi Pendidikan Dokter Gigi \\ ${ }^{3}$ Fakultas Kedokteran Universitas Sam Ratulangi \\ Email: myrtleirene@ymail.com
}

\begin{abstract}
Abstrak: Kesehatan gigi dapat terganggu oleh adanya karies. Gigi yang karies dapat dikembalikan fungsinya dengan cara membuang jaringan karies dan merestorasinya dengan material restorasi. Salah satu material restorasi yang digunakan di Poli Gigi RS Bhayangkara Manado ialah Semen ionomer kaca (SIK). Tujuan dari penelitian ini untuk mengetahui gambaran penggunaan material restorasi SIK di Poli Gigi RS Bhayangkara Manado tahun 2011 - 2013 berdasarkan waktu penumpatan, usia pasien, regio gigi dan jenis kelamin. Desain penelitian ini yaitu deskriptif dengan pendekatan cross sectional. Sampel penelitian berjumlah 55 rekam medik dan 67 tindakan. Berdasarkan waktu penumpatan, pada tahun 2011 terdapat 11 penumpatan dan mengalami peningkatan pada tahun 2012 menjadi 17 penumpatan dan tahun 2013 menjadi 39 penumpatan. Distribusi frekuensi usia berdasarkan waktu penumpatan, pasien usia dewasa lebih banyak terdapat penumpatan dibanding kelompok umur lainnya. Frekuensi regio gigi berdasarkan tahun restorasi didapatkan hasil penumpatan paling banyak pada posterior. Berdasarkan jenis kelamin, jumlah penumpatan paling banyak pada jenis kelamin perempuan dibanding laki-laki.
\end{abstract}

Kata kunci: Semen ionomer kaca, material restorasi, RS Bhayangkara Manado

\begin{abstract}
Dental health can be damage by the caries. Dental caries can be restored by removing carious tissue and restore it with restoration materials.One of the restorative material that used in Poly Dental of Manado Bhayangkara Hospital is Glass ionomer cement (GIC). The purpose of this research is to describe the use of restorative material GIC at Poly Dental of Manado Bhayangkara Hospital years 2011 - 2013, based on years of restoration, age, dental regions and gender.This research is a descriptive research that used cross sectional approach. The study sample number is 55 medical record and 67 action. Based on the time of fillings, in 2011 there were 11 fillings. It increased in 2012 to 17 fillings and in 2013 to 39 dental fillings. The frequency distribution of age base on years of restoration, adult patients get more fillings than other age groups. The frequency of dental regions based on years restoration show that teeth fillings most occur in posterior. By gender, the number of teeth fillings most occur in the female than male.
\end{abstract}

Keywords: Glass ionomer cement, restorative materials, Manado Bhayangkara Hospital

Tubuh sehat merupakan salah satu aspek penting dalam menunjang kehidupan manusia. Kesehatan gigi dan mulut merupakan aspek dari kesehatan secara umum. ${ }^{1}$ Banyak hal yang dapat membuat kesehatan gigi terganggu. Salah satu hal yang dapat membuat kesehatan gigi terganggu ialah penyakit karies.

Karies adalah penyakit pada jaringan keras gigi yang ditandai oleh adanya demineralisasi mineral-mineral dentin dan diikuti oleh kerusakan bahan-bahan 
organiknya. $^{2}$ Menurut World Health Organization (WHO), sejumlah 60\% - 90\% anak sekolah dan orang dewasa mengalami karies. $^{3}$

Riset Kesehatan Dasar (RISKESDAS) tahun 2007 menyatakan bahwa prevalensi rata-rata penduduk Indonesia bermasalah gigi dan mulut sebesar $23,4 \%$, untuk ratarata nasional sebesar 4,85\%. ${ }^{4}$ Berdasarkan Riset Kesehatan Dasar (RISKESDAS) tahun 2013, menyatakan prevalensi nasional masalah gigi dan mulut ialah 25,9\% dan sebanyak 14 provinsi mempunyai prevalensi masalah gigi dan mulut diatas angka nasional. ${ }^{5}$ Hal ini menunjukkan meningkatnya persentase masalah penduduk Indonesia mengenai gigi dan mulut.

Salah satu cara penanggulangan karies yaitu membuang jaringan karies dan merestorasinya dengan material restorasi, hal ini dilakukan untuk mengembalikan fungsi gigi. Material restorasi memiliki fungsi untuk memperbaiki dan merestorasi struktur gigi yang rusak. ${ }^{4}$

Pasien dan dokter gigi mempunyai banyak pilihan yang bervariasi dalam memilih material dan prosedur untiuk merestorasi gigi yang berlubang akibat karies. Material-material restorasi yang digunakan yaitu amalgam, komposit dan semen ionomer kaca (SIK). Material restorasi SIK memiliki beberapa tipe. Pada penulisan ini membahas mengenai SIK tipe II sebagai bahan restorasi.

Semen ionomer kaca sering digunakan sebagai material restorasi dalam praktik kedokteran gigi di Puskesmas, rumah sakit, klinik, dan balai pengobatan serta praktik pribadi. Salah satu instansi rumah sakit yang menggunakan SIK yaitu Poli Gigi Rumah Sakit Bhayangkara (RS Bhayangkara) Manado. Rumah Sakit Bhayangkara Manado merupakan instansi rumah sakit kepolisian yang mempunyai poli gigi. Poli gigi di RS Bhayangkara Manado melakukan beberapa tindakan pelayanan medik pada pasien yang berkunjung. Salah satu tindakan pelayanan medik yang dilakukan ialah restorasi gigi.

Penulis tertarik melakukan penelitian mengenai gambaran penggunaan material restorasi SIK di Poli Gigi RS Bhayangkara Manado karena belum pernah ada data statistik mengenai penelitian tersebut.

\section{BAHAN DAN METODE}

Penelitian ini merupakan jenis penelitian deskriptif dengan pendekatan cross sectional yang dilaksanakan pada bulan Agustus 2014 di Poli Gigi Rumah Sakit Bhayangkara Manado yang berlokasi di Jl.Sam Ratulangi No.326 Kecamatan Wanea, Kota Manado, Provinsi Sulawesi Utara. Metode pengambilan sampel yang digunakan ialah metode total sampling. Populasi pada penelitian ini ialah total dari populasi rekam medis pasien yang dirawat dengan menggunakan material restorasi SIK di Poli Gigi RS Bhayangkara Manado selama tahun 2011 sampai tahun 2013. Alat dan bahan yang digunakan yaitu alat tulis, format isian rekam medis dan kamera, rekam medis pasien yang giginya ditumpat dengan SIK.

\section{HASIL PENELITIAN}

Data dikumpulkan dan dikelompokkan berdasarkan waktu penumpatan, usia pasien, regio gigi dan jenis kelamin. Data yang dikelompokkan kemudian dijumlahkan. Data yang dijumlah dimaksudkan untuk mendapatkan total penggunaan material restorasi di Poli Gigi RS Bhayangkara Manado. Total pasien yang tercatat mempunyai riwayat penumpatan gigi menggunakan material restorasi SIK di Poli Gigi RS Bhayangkara Manado pada tahun 2011 - 2013 yaitu 55 orang dengan 67 tindakan yang terdapat pada Tabel 1- 4

Tabel 1. Distribusi frekuensi SIK berdasarkan waktu penumpatan

\begin{tabular}{ccc}
\hline $\begin{array}{c}\text { Waktu } \\
\text { penumpatan } \\
\text { (Tahun) }\end{array}$ & $\mathbf{n}$ & $\mathbf{\%}$ \\
\hline 2011 & 11 & 16,4 \\
2012 & 17 & 25,4 \\
2013 & 39 & 58,2 \\
Total & 67 & 100 \\
\hline
\end{tabular}


Sarjono, Wicaksono, Pangemanan; Gambaran Penggunaan Material Restorasi...

Tabel 2. Distribusi frekuensi kategori usia pasien berdasarkan waktu penumpatan

\begin{tabular}{lcccccccc}
\hline $\begin{array}{l}\text { Kategori } \\
\text { umur }\end{array}$ & \multicolumn{2}{c}{$\mathbf{2 0 1 1}$} & \multicolumn{2}{l}{$\mathbf{2 0 1 2}$} & \multicolumn{2}{c}{$\mathbf{2 0 1 3}$} & \multicolumn{2}{c}{ Total } \\
\cline { 2 - 9 } & $\mathrm{n}$ & $\%$ & $\mathrm{n}$ & $\%$ & $\mathrm{n}$ & $\%$ & $\mathrm{n}$ & $\%$ \\
\hline $\begin{array}{l}\text { Anak }- \\
\text { anak }\end{array}$ & 3 & 27,3 & 0 & 0,0 & 3 & 7,7 & 6 & 9 \\
Remaja & 0 & 0,0 & 0 & 0,0 & 5 & 12,8 & 5 & 7,4 \\
Dewasa & 8 & 72,2 & 17 & 100 & 31 & 79,5 & 56 & 83,6 \\
Total & 11 & 100 & 17 & 100 & 39 & 100 & 67 & 100 \\
\hline
\end{tabular}

Tabel 3. Distribusi frekuensi regio gigi berdasarkan waktu penumpatan

\begin{tabular}{lcccccccc}
\hline \multirow{2}{*}{$\begin{array}{l}\text { Regio } \\
\text { gigi }\end{array}$} & \multicolumn{2}{c}{$\mathbf{2 0 1 1}$} & \multicolumn{2}{c}{$\mathbf{2 0 1 2}$} & \multicolumn{2}{c}{$\mathbf{2 0 1 3}$} & \multicolumn{2}{c}{ Total } \\
\cline { 2 - 9 } & $\mathrm{n}$ & $\%$ & $\mathrm{n}$ & $\%$ & $\mathrm{n}$ & $\%$ & $\mathrm{n}$ & $\%$ \\
\hline Anterior & 2 & 18,1 & 1 & 5,9 & 7 & 18 & 10 & 15 \\
Posterior & 9 & 81,9 & 16 & 94,1 & 32 & 82 & 57 & 85 \\
Total & 11 & 100 & 17 & 100 & 39 & 100 & 67 & 100 \\
\hline
\end{tabular}

Tabel 4. Distribusi frekuensi jenis kelamin berdasarkan waktu penumpatan

\begin{tabular}{lcccccccc}
\hline \multirow{2}{*}{$\begin{array}{l}\text { kenis } \\
\text { kelamin }\end{array}$} & \multicolumn{2}{c}{$\mathbf{2 0 1 1}$} & \multicolumn{2}{c}{$\mathbf{2 0 1 2}$} & \multicolumn{2}{c}{$\mathbf{2 0 1 3}$} & \multicolumn{2}{c}{ Total } \\
\cline { 2 - 9 } & $\mathrm{n}$ & $\%$ & $\mathrm{n}$ & $\%$ & $\mathrm{n}$ & $\%$ & $\mathrm{n}$ & $\%$ \\
\hline Laki - laki & 7 & 63,6 & 6 & 35,3 & 12 & 30,8 & 25 & 37,3 \\
Perempuan & 4 & 36,4 & 11 & 64,7 & 27 & 69,2 & 42 & 62,7 \\
Total & 11 & 100 & 17 & 100 & 39 & 100 & 67 & 100 \\
\hline
\end{tabular}

\section{BAHASAN}

Berdasarkan waktu penumpatan, dari hasil penelitian diperoleh penggunaan material restorasi SIK meningkat di tahun 2013 yaitu berjumlah 39 penumpatan (58,2\%) dibanding dengan tahun 2011 yang berjumlah 11 penumpatan $(16,4 \%)$ dan pada tahun 2012 yang berjumlah 17 penumpatan (25,4\%). Distribusi ini menunjukkan penggunaan material restorasi SIK di Poli Gigi RS Bhayangkara Manado meningkat dari tahun ke tahun. Material restorasi SIK memiliki sifat yang sewarna dengan gigi ${ }^{6}$ sehingga hal inilah yang membuat masyarakat lebih menyukai material restorasi SIK untuk menumpat selain itu harga dari material restorasi SIK yang lebih terjangkau. Material restorasi SIK yang memiliki sifat anti karies, sifat melepaskan fluor ${ }^{7}$ selama didalam mulut ${ }^{8}$ sehingga memberikan perlindungan terhadap terjadinya karies sekunder ${ }^{5}$ juga membuat penggunaan material restorasi SIK meningkat.

Material restorasi SIK tidak hanya digunakan pada bagian anterior, tetapi digunakan juga pada bagian posterior untuk penumpatan gigi sehingga penggunaan material restorasi SIK dari tahun ke tahun kian meningkat. Material restorasi komposit sedikit digunakan karena walaupun material restorasi komposit sewarna dengan gigi tetapi harganya yang relatif lebih mahal dibandingkan material restorasi SIK. Material restorasi SIK yang lebih murah daripada material restorasi komposit dan memiliki warna yang lebih menyerupai gigi menjadikan material restorasi SIK sebagai pilihan yang ideal.

Distribusi frekuensi kategori usia berdasarkan waktu penumpatan penggunaan material restorasi SIK paling banyak dilakukan pada usia dewasa yaitu berjumlah 56 penumpatan $(83,6 \%)$. Usia anak tercatat enam penumpatan $(9 \%)$, remaja tercatat lima penumpatan $(7,4 \%)$. Seperti halnya dengan penelitian yang dilakukan di Rumah Sakit Gigi dan Mulut Fakultas Kedokteran Gigi Universitas Indonesia (RSGM FKG UI), tercatat usia dewasa paling banyak dilakukan penumpatan menggunakan material restorasi SIK dengan jumlah 269 penumpatan (73,9\%). Usia anak-anak berjumlah 44 penumpatan $(12,1 \%)$, remaja 43 penumpatan $(11,8 \%))^{9} \quad$ Penelitian yang dilakukan oleh Sumolang di Poli Gigi RS Gunung Maria terdapat kelompok usia dewasa merupakan usia yang paling banyak menggunakan material restorasi SIK sebanyak 58,8\%. ${ }^{10}$ Hasil penelitian dilakukan oleh Tulaka di RS Wolter Monginsidi Manado yang merupakan rumah sakit angkatan darat menunjukkan hasil bahwa kelompok usia dewasa menggunakan material restorasi SIK yaitu $79,2 \%{ }^{11}$

Usia dewasa merupakan usia produktif. Usia dewasa cenderung memiliki kesadaran diri terhadap estetika dan memerhatikan pentingnya kesehatan terutama kesehatan gigi dan mulut. Usia remaja saat ini lebih banyak mendapatkan pengetahuan mengenai kesehatan gigi dan mulut dari sekolah, 
orangtua, media sosial dan sebagainya sehingga hal ini dapat mengurangi tingkat karies pada remaja. Usia anak-anak belum memiliki kesadaran diri mengenai pentingnya kesehatan terutama kesehatan gigi dan mulut. Anak-anak belum mengerti mengenai pentingnya menjaga dan memelihara kesehatan terutama kesehatan gigi dan mulut. Anak-anak biasanya datang ke dokter gigi karena keinginan dari orang tua.

Hasil distribusi regio gigi berdasarkan waktu penumpatan, regio gigi posterior berjumlah 57 penumpatan (85\%) merupakan gigi yang paling sering ditumpat dengan material restorasi SIK. Regio gigi anterior tercatat sebanyak 10 penumpatan (15\%). Penelitian di Amerika pada tahun 2009 tercatat sekitar $90 \%$ karies terdapat pada regio gigi posterior. ${ }^{12}$ Hal ini sesuai dengan hasil penelitian yang dilakukan di Poli Gigi RS Gunung Maria Tomohon, regio gigi posterior merupakan regio yang paling banyak ditumpat dengan material restorasi SIK sebanyak $84,4 \% .{ }^{10}$ Penelitian yang dilakukan oleh Saerang juga menunjukkan hasil yang sama yaitu regio gigi posterior merupakan regio gigi yang paling banyak ditumpat menggunakan material resorasi SIK yaitu sebanyak $64,5 \%{ }^{13}$

Regio gigi posterior lebih banyak mendapatkan penumpatan dengan material restorasi SIK, hal ini disebabkan oleh permukaan gigi posterior yaitu premolar dan molar yang memiliki pit dan fisur yang cukup dalam sehingga menjadi tempat ideal untuk menempelnya sisa-sisa makanan dan bakteri penyebab karies. Letak gigi premolar dan molar yang berada di posterior sehingga menyulitkan untuk membersihkan gigi-gigi tersebut saat menyikat gigi, oleh karena itu debris dan plak mudah menumpuk yang semakin memperbesar kemungkinan terjadinya karies.

Tindakan penumpatan menggunakan material restorasi SIK untuk jenis kelamin waktu penumpatan restorasi tercatat perempuan lebih banyak mendapatkan tindakan penumpatan yaitu 42 tindakan (62,7\%). Laki-laki lebih sedikit mendapatkan tindakan penumpatan, tercatat sebanyak 25 tindakan (37,3\%). Penelitian yang dilakukan di
RSGM FKG UI diketahui bahwa perempuan merupakan yang paling sering melakukan tindakan penumpatan yaitu sebanyak 62,3 \% dibandingkan dengan laki-laki yaitu 37,7\%. ${ }^{9}$ Hal ini sebanding dengan hasil penelitian yang dilakukan Sumolang yaitu perempuan lebih banyak menggunakan material restorasi SIK yaitu sebanyak 101 orang (56\%). ${ }^{10}$ Menurut data American Dental Association (ADA) menunjukkan bahwa perempuan sebanyak $89 \%$ lebih rutin datang ke dokter gigi untuk melakukan perawatan dibandingkan dengan laki-laki. ${ }^{14}$ Pada penelitian yang dilakukan di RSGM Program Studi Pendidikan Dokter Gigi Fakultas Kedokteran Universitas Sam Ratulangi juga menunjukkan hasil yang sama yaitu jenis kelamin perempuan paling sering melakukan tindakan penumpatan menggunakan material SIK tercatat 56,3\%. ${ }^{13}$

Perempuan lebih banyak mendapatkan tindakan penumpatan daripada laki-laki karena perempuan lebih menjaga dan memperhatikan estetik dan kesehatan gigi mulut dibandingkan laki-laki. Menjaga penampilan terutama memperhatikan estetik dan kesehatan gigi dan mulut dapat membuat perempuan lebih percaya diri.

\section{SIMPULAN}

Gambaran penggunaan material restorasi SIK di Poli Gigi RS Bhayangkara Manado tahun 2011 - 2013 dapat disimpulkan bahwa penggunaan material restorasi SIK pada tahun 2013 paling banyak dilakukan dibandingkan dengan tahun 2011 dan tahun 2012. Penggunaan material restorasi SIK sebagai tumpatan paling banyak dilakukan pada pasien dengan kategori usia dewasa dibanding dengan pasien usia anak dan remaja. Jumlah tindakan penumpatan dengan material restorasi SIK paling banyak dilakukan pada regio gigi posterior dibanding dengan regio gigi anterior. Material restorasi SIK lebih banyak digunakan pada pasien perempuan.

\section{SARAN}

Bagi Instansi Rumah Sakit diharapkan dapat bermanfaat sebagai data statistik 
untuk peningkatan mutu pelayanan kesehatan gigi dan mulut khususnya pada penggunaan material restorasi SIK. Diharapkan masyarakat khususnya anggota kepolisian mendapatkan pengetahuan mengenai SIK sehingga menjadi pertimbangan dalam pemilihan material restorasi gigi.

\section{DAFTAR PUSTAKA}

1. Chrisopoulos S, Harford J. Oral health and dental care in Australia Key facts and figures 2013. Canberra: Australian Institute of Health and Welfare.2013. p.10.

2. Medika W. Manual Konservasi Restoratif Menurut Pickard. ed 6. 2012. Jakarta: h 357.

3. World Health Organitazion (WHO). Media Center Oral Health. 2012.[serial online p: 318

4. Balitbangkes. Riset Kesehatan Dasar (RISKESDAS) 2007: Laporan Nasional 2007. Badan Penelitian dan Kesehatan. Departemen Kesehatan, Departemen Republik Indonesia. Desember 2008.h. 10.

5. Balitbangkes. Riset Kesehatan Dasar (RISKESDAS) 2013: Laporan Nasional 2013. Badan Penelitian dan Kesehatan. Departemen Kesehatan, Departemen Republik Indonesia.Desember 2013.h x.

6. Melzarini A, Irmawati. Kekerasan permukaan semen ionomer kaca konvensional tipe II akibat lama penyimpanan. Maj ked. Gigi (Dent J) julsept 2005; 38(3): 146-9.

7. Hakim R. Gambaran tumpatan glass ionomer cement pada mahasiswa akademi keperawatan rumah sakit tingkat III Robert wolter monginsidi. Jurnal e-GiGi Juli-Desember 2013; 1 (2): 1.

Ejournal.unsrat.ac.id/index.php/egigi/arti cle/view/3229
8. Rovani P. Ilmu Bahan Kedokteran Gigi. Makassar: Fakultas Kedokteran Gigi Universitas Hasanuddin Makassar; 2005. h.194-200

9. Indriani. Survei pemaparan penggunaan amalgam, GIC dan resin komposit sebagai bahan tumpatan gigi di RSGMP FKG UI pada tahun 2005, 2006, 2007. Fakultas Kedokteran Gigi UI; 2008.

10. Sumolang M, Wicaksono D A, Abidjulu J. Gambaran penggunaan resin komposit dan semen ionomer kaca sebagai bahan restorasi di Poli Gigi Rumah Sakit Gunung Maria Tomohon Tahun 2012.Jurnal e-GiGi (eG) Juli-Desember 2013; 1 (2):1 https://203.130.254.141/index.php/egigi/art icle/view/3215

11. Tulaka B, Wicaksono D A. Tumewu E. Gambaran Penggunaan Semen Ionomer Kaca Sebagai Bahan Tumpatan di Rumah Sakit Robert Wolter Monginsidi Manado tahun 2011-2013. Jurnal e-GiGi (eG) JuliDesember 2014; 2 (2): 1. ejournal.unsrat.ac.id/index.php/egigi/article /view/5034

12. Zero D. Fontana M, Martinez E, Ferreita A, Ando M, Gonzales C, et al. The biology, prevention, diagnosis and treatment of dental caries: scientific advances in the United States. J Am Dent Assoc.2009. p. 140:25-34

13. Saerang G S. Lampus BD. Wicaksono DA. Gambaran Penggunaan Semen Ionomer Kaca Sebagai Bahan Tumpatan Gigi dibalai Pengobatan Rumah Sakit Gigi dan Mulut Universitas Sam Ratulangi pada Tahun 2011 sampai 2012.Jurnal e-GiGi (eG)nJuli Desember 2013; 1(2):1 https://203.130.254.141/index.php/egigi/art icle/view/3230

14. Delta denta of Minnesota. Men and oral health. Decare international. [Online] 2006 [cited 2013 sep 9] Available from: URL: http://web.augsburg.edu/hr/wellness/dental/ 091306.pdf 